\title{
Effect of Microwave Disinfection on Denture Base Adaptation and Resin Surface Roughness
}

\author{
Evandro Afonso SARTORI \\ Caroline Bom SCHMIDT \\ Luiz Fernando WALBER \\ Rosemary Sadami Arai SHINKAI \\ Department of Prosthodontics, Dental School, \\ Pontifical Catholic University of Rio Grande do Sul, Porto Alegre, RS, Brazil
}

\begin{abstract}
This study evaluated the effect of disinfection methods [chemical disinfection (immersion in 100 ppm chloride solution) or microwave disinfection (690 $\mathrm{W}$ for $6 \mathrm{~min}$ )] on the internal adaptation of denture bases and resin surface roughness. For the adaptation test, 18 maxillary denture bases were obtained from stone casts duplicated from a metallic master model and submitted to the following treatments: 1) control (no disinfection), 2) chemical disinfection or 3) microwave disinfection. Disinfection procedures were performed twice (T1, T2) with a 7-day interval between them. Internal adaptation was measured at baseline (T0) and after T1 and T2 by weighing a vinyl polysiloxane film reproducing the gap between the resin base and the master model. For surface roughness measurement, 60 rectangular (5x10x40 mm) resin specimens were either mechanically or chemically polished and then submitted to the disinfection treatments. Surface roughness $(R a)$ was recorded after polishing (T0) and after T1 and T2. Data were analyzed by ANOVA GLM for repeated measures and Bonferroni correction at $5 \%$ significance level. Bases submitted to microwave disinfection had gradual increase of misfit, while bases immersed in chloride solution did not differ from the control group. Surface roughness increased in the mechanical polishing groups with microwave disinfection and decreased in the chemical polishing groups.
\end{abstract}

Key Words: acrylic resin, complete dentures, microwave disinfection, internal adaptation, surface roughness.

\section{INTRODUCTION}

Adequate maintenance of removable prostheses is needed for denture wearers to have an esthetic, odorfree appliance and good oral health. Oral problems related to poor hygiene of dentures support the need to establish a disinfection protocol that is effective, clinically viable, inexpensive and easy to comply with. Chemical disinfection of dentures is commonly achieved by soaking in alkaline glutaraldehyde, sodium hypochlorite, aqueous formaldehyde or enzymatic solutions (12). More recently, microwave irradiation has been considered for denture sterilization/disinfection instead of chemical solutions because it requires no special storage, has no expiration date and does not induce resistance to Candida albicans (3-5).

The available disinfection methods for complete and partial dentures are still controversial because they may alter some material properties and clinical features. For instance, alcohol-based disinfectants reduce the flexural strength of non-crosslinked denture base acrylic resins (6). Surface alteration may occur by continuous use of some disinfection methods, e.g., staining (by soaking in chlorhexidine) or bleaching (by soaking in sodium hypochlorite). Surface roughness of denture base resins also might be modified depending on the initial surface quality and disinfection procedure.

Two polishing procedures are currently available: mechanical and chemical polishing. Chemical polishing was first introduced by Gotusso (7), who proposed immersing the prosthesis in methyl methacrylate liquid heated at $70^{\circ} \mathrm{C}$ for $1 \mathrm{~min}$. To date, the technique uses immersion in a specific chemical solution made of monomer and stabilizers (hydroquinone) at $75^{\circ} \mathrm{C}$ for 10

Correspondence: Profa. Dra. Rosemary Sadami Arai Shinkai, Faculdade de Odontologia, PUCRS, Avenida Ipiranga, 6681, Predio 6, 90619900 Porto Alegre, RS, Brasil. Tel: +55-51-3320-3538. Fax: +55-51-3320-3626. e-mail: rshinkai@pucrs.br 
s (8). Although faster and easier than the mechanical polishing, chemical polishing may reduce surface hardness $(9)$ and transverse strength $(8,10)$, and increase residual monomer content (9) and resin solubility (11). Because chemical polishing modifies resin surface roughness $(9,12)$, disinfection procedures might additionally compromise surface texture over time.

Another clinically relevant property that may be affected by disinfection methods is the dimensional stability of denture bases. Disinfection procedures may modify the internal adaptation of denture bases due to resin solubility or water sorption from soak-chemical disinfection or excessive heat from microwaving. Previous studies on microwave disinfection assessed linear measurements in selected points of dentures (3) or rectangular specimens (1), but there is a lack of data on tridimensional distortion of denture bases.

Therefore, this study evaluated the effect of chemical and microwave disinfection methods on internal adaptation of denture bases and on surface roughness of a microwave-polymerized denture base resin.

\section{MATERIAL AND METHODS}

\section{Evaluation of Denture Base Internal Adaptation}

Eighteen specimens were fabricated with a heatpolymerized poly(methyl metacrylate) denture base resin (Veracril; New Stetic Dental Ltda, Petrópolis, RJ, Brazil). A vinyl polysiloxane impression (Elite Doublé, Zhermack, Rovigo, Italy) was obtained from a metallic master model of an edentulous maxilla and poured with type III dental stone. This master cast had delimitation of the denture basal area and three projections (one anterior and two posterior) to ensure later repositioning of resin bases for the internal adaptation test.

An approximately 2-mm-thick denture baseplate was waxed up on each stone cast. The wax baseplate/ cast sets were invested in plastic flasks for microwave polymerization following standard procedures. The resin was prepared and packed according to the manufacturer's directions by a sigle operator to avoid inter-subject variation. Polymerization was done in a microwave oven (LG Electronics, Model MS-115ML, São Paulo, SP, Brazil; output $1150 \mathrm{~W} / \mathrm{h}$, with 2D rotating plate) according to the resin manufacturer's instructions (3 min at $345 \mathrm{~W}, 4 \mathrm{~min}$ of pause and $3 \mathrm{~min}$ at $690 \mathrm{~W}$ ). After bench cooling to room temperature, the bases were deflasked, trimmed and randomly assigned to 3 groups $(n=6)$ to receive different disinfection treatments: Control (no disinfection); Chemical disinfection: immersion in $100 \mathrm{ppm}$ active chloride solution for $24 \mathrm{~h}$. The solution was prepared with $500 \mathrm{~mL}$ of distilled water and one effervescent chlorine disinfectant tablet (Aquatabs Family Bayer, Medentech Ltd, Wexford, Ireland); Microwave disinfection: immersion in $500 \mathrm{~mL}$ of distilled water and microwave irradiation at $690 \mathrm{~W}$ for 6 min [adapted from Neppelenbroek et al. (13)].

All groups were stored in water at $37^{\circ} \mathrm{C}$ between two disinfection procedures (T1 and T2) with a 7-day interva and were coded with random letters to blind the examiner during adaptation recording.

Internal adaptation was measured by the method of weighing a silicon film reproducing the gap between resin base and metallic master model (14). A standardized portion of a flow type vinyl polysiloxane impression material (Express; 3M/ESPE, St. Paul, MN, USA) was mixed and coated the internal surface of the resin bases, which were positioned onto the master cast under a 4 kgf-axial load. After polymerization, the resulting silicon film was trimmed at the borderline mark of the master cast and weighed using a precision scale accurate to 0.0001g (model AG204, Mettler Toledo, Switzerland). This procedure was done immediately after base polishing (baseline - T0) and after each of the two weekly disinfection procedures (T1 and $\mathrm{T} 2$ ).

\section{Evaluation of Surface Roughness}

Rectangular resin specimens (40x10x5mm) were prepared (Veracril; New Stetic Dental Ltda). Polymerization and cooling followed the same protocol as described for the internal adaptation test. After deflasking, resin flash was removed with a finishing bur at low speed. The test surface was ground with 400-, 600- and 1200-grit silicon carbide paper in a water-cooled polishing machine (model DPU-10, Struers/Panambra Industrial e Técnica SA, São Paulo, SP, Brazil) for $10 \mathrm{~s}$. Specimens were randomly assigned to two groups to receive either mechanical or chemical polishing.

Mechanical polishing was done on a bench lathe with pumice slurry for $30 \mathrm{~s}$ and chalk slurry for $30 \mathrm{~s}$. For chemical polishing, a chemical polishing machine (PQ9000 Termotron, Termotron do Brasil Ltda, Piracicaba, SP, Brazil) was used; specimens were immersed in polishing fluid (Poli-Quim, Artigos Odontológicos 
Clássico, São Paulo, SP, Brazil) at $75^{\circ} \mathrm{C}$ for $10 \mathrm{~s}$, benchdried for $15 \mathrm{~s}$ and washed in running water for $15 \mathrm{~s}$.

The polished specimens were randomly assigned to 6 groups $(\mathrm{n}=10)$ according to the disinfection treatment: 1) Chemical polishing, microwave disinfection; 2) Chemical polishing, chemical disinfection; 3) Chemical polishing, no disinfection; 4) Mechanical polishing, microwave disinfection; 5) Mechanical polishing, chemical disinfection; and 6) Mechanical polishing, no disinfection. Disinfection procedures followed the same protocol as described for the internal adaptation test.

Average surface roughness $(R a)$ was measured using a surface analyzer surface roughness tester (SJ201; Mitutoyo Corporation, Japan) accurate to 0.01 $\mu \mathrm{m}$. Each specimen was measured in duplicate and $R a$ means were calculated. $R a$ was recorded after the polishing procedure (baseline - $\mathrm{T} 0$ ) and after each of the two weekly disinfection procedures (T1 and T2).

Preliminary tests showed normal data distributions and parametric statistical tests were chosen. Internal adaptation and surface roughness data were analyzed using ANOVA GLM for repeated measures, and pos-hoc pairwise comparison of means was done with Bonferroni correction. All tests were two-tailed, and signficance level as set at $5 \%(\mathrm{p}<0.05)$.

Table 1. Internal adaptation (in g) of the groups $(n=6)$ at baseline (T0) and after disinfection procedures (T1 and T2).

\begin{tabular}{lc}
\hline Disinfection Method & Mean \pm SD (g) \\
\hline Microwave disinfection & \\
T0 & $2.79 \pm 0.53 \mathrm{a}$ \\
T1 & $6.42 \pm 1.62 \mathrm{~b}$ \\
T2* & - \\
Chemical disinfection & \\
T0 & $3.00 \pm 0.56 \mathrm{a}$ \\
T1 & $3.75 \pm 0.64 \mathrm{a}$ \\
T2 & $3.80 \pm 0.77 \mathrm{a}$ \\
& \\
Control (no disinfection) & \\
T0 & $2.88 \pm 0.65 \mathrm{a}$ \\
T1 & $4.54 \pm 0.54 \mathrm{a}$ \\
T2 & $4.41 \pm 0.97 \mathrm{a}$ \\
\hline
\end{tabular}

Different letters indicate statistically significant difference (ANOVA GLM and Bonferroni correction; $\mathrm{p}<0.05$ ). * = Noncollected data due to excessive base distortion.

\section{RESULTS}

The results of the internal adaptation and surface roughness tests for each experimental group are given on Tables 1 and 2.

Because of the distortion of resin bases in the microwave disinfection group after the second disin-

Table 2. Surface roughness means $(R a ; \mu \mathrm{m})$ of the groups $(\mathrm{n}=10)$ at baseline (T0) and after disinfection procedures (T1 and T2).

\begin{tabular}{ll}
\hline Polishing/Disinfection Method & Mean \pm SD $(\mu \mathrm{m})$ \\
\hline $\begin{array}{l}\text { Chemical polishing/ } \\
\text { Microwave disinfection }\end{array}$ \\
T0 \\
T1 \\
T2 & $0.594 \pm 0.204 \mathrm{a}$ \\
& $0.490 \pm 0.142 \mathrm{~b}$ \\
Chemical polishing/ & $0.482 \pm 0.147 \mathrm{~b}$ \\
Chemical disinfection & \\
T0 & \\
T1 & \\
T2 & $0.559 \pm 0.125 \mathrm{a}$ \\
& $0.522 \pm 0.131 \mathrm{a}$ \\
& $0.517 \pm 0.136 \mathrm{a}$
\end{tabular}

Chemical polishing/

No disinfection

T0

$\mathrm{T} 1$

$0.466 \pm 0.164 \mathrm{a}$

$\mathrm{T} 2$

$0.437+0.110$

$0.467 \pm 0.207 \mathrm{a}$

Mechanical polishing/

Microwave disinfection T0

$0.069 \pm 0.311 \mathrm{a}$

$\mathrm{T} 1$

$0.152 \pm 0.044 b$

T2

$0.169 \pm 0.041 b$

Mechanical polishing/

Chemical disinfection

T0

$0.071 \pm 0.019 \mathrm{a}$

$\mathrm{T} 1$

$0.070 \pm 0.025 \mathrm{a}$

$\mathrm{T} 2$

$0.069 \pm 0.026 \mathrm{a}$

Mechanical polishing/

No disinfection

T0

$0.078 \pm 0.034 \mathrm{a}$

T1 $0.071 \pm 0.030 \mathrm{a}$

T2 $0.071 \pm 0.028 \mathrm{a}$

Different letters indicate statistically significant difference (ANOVA GLM and Bonferroni correction; $\mathrm{p}<0.05$ ). 
fection procedure (T2), it was not possible to collect data from this group. Thus, ANOVA GLM for repeated measures was used for $\mathrm{T} 0, \mathrm{~T} 1$, and $\mathrm{T} 2$ data for the control and chemical disinfection groups and for $\mathrm{T} 0$ and T1 data for microwave disinfection group. The factor "Time" $(\mathrm{p}<0.001)$ and the interaction "Time X Group" $(p<0.001)$ were significant. No significant difference between chemical disinfection and control groups was observed over time, as well as compared to the baseline adaptation (T0) of the microwave disinfection group. The microwave disinfection group showed a statistically significant increase of misfit in $\mathrm{T} 1$ compared to the other groups $(\mathrm{p}<0.001)$.

For both chemical and microwave disinfection methods, the chemical polishing groups showed the highest $R a$ values (Table 2). $R a$ values of the microwave disinfection groups were significantly different from the other groups $(\mathrm{p}<0.005)$. For the group of mechanical polishing and microwave disinfection, a significant increase of roughness was observed from $\mathrm{T} 0$ to $\mathrm{T} 1$, but $\mathrm{Ra}$ remained constant in T2. The group of chemical polishing and microwave disinfection showed significant reduction of surface roughness in $\mathrm{T} 1$, which was not modified in T2. For chemical disinfection groups and control groups, $R a$ was not different over time for mechanical and chemical polishing methods.

\section{DISCUSSION}

In this study, repeated disinfection procedures by microwave irradiation negatively affected the internal adaptation of denture bases and the surface roughness of a microwave-polymerized denture base resin.

Regarding internal adaptation, denture bases submitted to microwave disinfection had significant decrease of adaptation, while bases immersed in chloride solution and the control group remained dimensionally stable over time. However, although not significant, there was a trend of increasing internal misfit of the resin bases, which may be explained by water sorption (15). The internal adaptation after the second microwave disinfection procedure could not measured because the denture bases had such a distortion that they did not adapt on the metallic master model. This suggests that a structural change occurred inside the resin bases submitted to the tested microwave irradiation protocol (690 W for $6 \mathrm{~min}$ ). Craig reported heat distortion when acrylic resins were heated from 71 to $90^{\circ} \mathrm{C}$ (15).
Veracril denture base resin is a heat-polymerized poly(methyl metacrylate) resin with a crosslinked structure and can be polymerized by microwave irradiation or boiling water according to the manufacturer. The microwave irradiation at $690 \mathrm{~W}$ for $6 \mathrm{~min}$ probably promoted a rearrangement of polymer chains leading to resin base distortion.

Previous studies have shown contradictory results of denture resin distortion after microwaving, which may be explained by the use of different irradiation protocols (power and time), materials and methods to measure distortion. A previous study (3) found that microwave disinfection at $604 \mathrm{~W}$ for 10 min caused linear dimensional alteration of complete dentures in vertical and horizontal directions, but reduced exposures (331 W for $6 \mathrm{~min}$ ) caused less alteration. In a previous study, microwave disinfection at 500W for 3 and 15 min did not promote clinically relevant linear alteration, but the test specimens were resin rectangles and not denture bases (1). On the other hand, other authors (16) reported that all denture bases polymerized by conventional water bath or microwave energy exhibited significant distortion after repair with microwavecured acrylic resin at $500 \mathrm{~W}$ for $3 \mathrm{~min}$.

Although several protocols have been proposed for microwave disinfection, there is no gold standard. Our protocol followed the study by Neppelenbroek et al. (13), who showed that microwave irradiation for $6 \mathrm{~min}$ at $650 \mathrm{~W}$ was effective for sterilization of hard chairside reline resins. All denture bases were immersed in distilled water because microwave irradiation in water environment is more effective to kill C. albicans than irradiation of dry specimens (4).

In relation to surface roughness, microwave energy also modified the surface texture of all groups. The average surface roughness increased in the mechanical polishing group and decreased in the group submitted to chemical polishing. Even with the increase of surface roughness in the mechanical polishing group, $R a$ values did not reach the baseline values of the chemical polishing group. Increased surface roughness of acrylic resins submitted to chemical polishing have been previously shown $(9,12)$. A scanning electron microscopic investigation showed that, in mechanically polished resin, the polishing brush and the slurry of pumice or calcium carbonate flatten the resin surface undulations and reduce the peaks, while chemical polishing promotes a smooth and wavy surface (9). The 
mean $R a$ values for all groups submitted to chemical polishing were superior to $0.2 \mu \mathrm{m}$, which has been considered a clinical threshold of surface roughness for biofilm accumulation (17).

Differently from microwave disinfection, chemical disinfection did not modify resin surface roughness, independently of the polishing technique. Surface texture was preserved when the resin specimens were immersed in chloride solution for $24 \mathrm{~h}$, which is longer than the immersion time often used by denture patients. Five chemical solutions and five denture resins were tested in a previous study (18); the magnitudes of change in surface roughness were statistically significant but clinically irrelevant after 7-day immersion. Other studies on chemical disinfectants with variable immersion periods also have shown no effect on flexural strength of heat-polymerized denture base resins (19), even mechanically or chemically polished (10).

Although chemical disinfection seems to be safer to physical properties of denture resins, microwave irradiation has proved to be more effective for denture sterilization and reduction of $C$. albicans re-infestation than immersion in sodium hypochlorite (20) or chlorhexidine (5) solutions. SEM examination shows irreversible alterations in cell morphology of microorganisms after microwave irradiation $(13,20)$. Also, Dixon et al. tested three soft denture liners and one heat-polymerized denture base resin and showed that repeated 5-min irradiation in a $60 \mathrm{~Hz}$ microwave oven only affected the hardness of PermaSoft (4).

A limitation of this study is the restricted generalization of our results to other types of denture base resins, e.g., resins polymerized by different techniques, hard and soft reliners. Also, we tested one microwave disinfection protocol and irradiated the specimens twice, but the resin dimensional stability and surface roughness after microwave irradiation for longer periods and with other protocols are unknown . Further studies should investigate different microwave disinfection protocols on different materials to assess if the deleterious effect of microwave irradiation is resin-specific.

\section{RESUMO}

Este estudo avaliou o efeito de métodos de desinfecção [desinfecção química (imersão em solução clorada 100 ppm) ou desinfecção por microondas (690 W por $6 \mathrm{~min}$ )] na adaptação interna de bases de próteses totais e na rugosidade superficial da resina. Para o teste de adaptação, 18 bases superiores foram duplicadas a partir de um modelo-mestre metálico e submetidas aos seguintes tratamentos: 1) controle (sem desinfecção), 2) desinfecção química ou 3) desinfecção por microondas. Os procedimentos de desinfecção foram realizados duas vezes (T1, T2) com intervalo de 7 dias. A adaptação interna foi medida no baseline (T0), após T1 e T2 por pesagem de um filme de silicona de adição que reproduzia o espaço entre base de resina e modelo-mestre. Para a rugosidade superficial, 60 espécimes retangulares (5x10×40 mm) receberam polimento mecânico ou químico e foram submetidos aos tratamentos de desinfecção. A rugosidade superficial $(R a)$ foi registrada após o polimento (T0) e após T1 e T2. Os dados foram analisados por ANOVA GLM para medições repetidas e teste de Bonferroni com nível de significância de 5\%. As bases submetidas à desinfecção por microondas tiveram aumento gradual de desadaptação, enquanto que as bases imersas em solução clorada não diferiram do grupo controle. A rugosidade superficial aumentou nos grupos de polimento mecânico e desinfecção por microondas e diminuiu nos grupos de polimento químico.

\section{ACKNOWLEDGEMENTS}

This study was supported by The State of Rio Grande do Sul Research Foundation (FAPERGS/BIC 02504431/2003) and the Pontifical Catholic University of Rio Grande do Sul.

\section{REFERENCES}

1. Polyzois GL, Zissis AJ, Yannikakis SA. The effect of glutaraldehyde and microwave disinfection on some properties of acrylic denture resin. Int J Prosthodont 1995;8:150-154.

2. Shay K. Denture hygiene: a review and update. J Contemp Dent Pract 2000;1:28-41.

3. Thomas CJ, Webb BC. Microwaving of acrylic resin dentures. Eur J Prosthodont Restor Dent 1995;3:179-182.

4. Dixon DL, Breeding LC, Faler TA. Microwave disinfection of denture base materials colonized with Candida albicans. J Prosthet Dent 1999;81:207-214.

5. Banting DW, Hill SA. Microwave disinfection of dentures for the treatment of oral candidiasis. Spec Care Dentist 2001;21:4-8.

6. Asad T, Watkinson AC, Huggett R. The effect of disinfection procedures on flexural properties of denture base acrylic resins. J Prosthet Dent 1992;68:191-195.

7. Gotusso MJ. Tratamiento químico e superficial de las resinas acrílicas [in Spanish]. Rev Assoc Odontol Argent 1969;57:359-361.

8. Nunes de Mello JA, Braun KO, Rached RN, Del Bel Cury AA. Reducing the negative effects of chemical polishing in acrylic resins by use of an additional technique of polymerization. J Prosthet Dent 2003;89:598-602.

9. Braun KO, Mello JAN, Rached RN, Del Bel Cury AA. Surface texture and some properties of acrylic resins submitted to chemical polishing. J Oral Rehabil 2003:30:91-98.

10. Orsi IA, Andrade VG. Effect of chemical disinfectants on the transverse strength of heat-polymerized acrylic resins submitted to mechanical and chemical polishing. J Prosthet Dent 2004;92:382-388.

11. Machado C, Rizzatti-Barbosa CM, Gabriotti MN, Joia FA, Ribeiro MC, Sousa RL. Influence of mechanical and chemical polishing in the solubility of acrylic resins polymerized by 
microwave irradiation and conventional water bath. Dent Mater 2004;20:565-569.

12. Rahal JS, Mesquita MF, Henriques GE, Nobilo MA. Surface roughness of acrylic resins submitted to mechanical and chemical polishing. J Oral Rehabil 2004;31:1075-1079.

13. Neppelenbroek KH, Pavarina AC, Spolidorio DM, Vergani CE, Mima EG, Machado AL. Effectiveness of microwave sterilization on three hard chairside reline resins. Int $\mathrm{J}$ Prosthodont 2003;16:616-620.

14. Ganzarolli SM, Rached RN, Garcia RC, Del Bel Cury AA. Effect of cooling procedure on final denture base adaptation. J Oral Rehabil 2002;29:787-790.

15. Craig RC. Prosthetic applications of polymers. In: Restorative dental materials. Craig RC (editor). 10th ed. Saint Louis: Mosby; 1997. p. 500-551.

16. Dyer RA, Howlett JA. Dimensional stability of denture bases following repair with microwave resin. J Dent 1994;22:236241.
17. Bollen CM, Lambrechts P, Quirynen M. Comparison of surface roughness of oral hard materials to the threshold surface roughness for bacterial plaque retention: a review of the literature. Dent Mater 1997;13:258-269.

18. Ma T, Johnson GH, Gordon GE. Effects of chemical disinfectants on the surface characteristics and color of denture resins. J Prosthet Dent 1997;77:197-204.

19. Pavarina AC, Machado AL, Giampaolo ET, Vergani CE. Effects of chemical disinfectants on the transverse strength of denture base acrylic resins. J Oral Rehabil 2003;30:10851089.

20. Webb BC, Thomas CJ, Harty DW, Willcox MD. Effectiveness of two methods of denture sterilization. J Oral Rehabil 1998;25:416-423. 